\title{
Endovascular Management of Vertebrobasilar Artery Dissecting Aneurysms
}

\section{Vertebrobaziler Arter Disekan Anevrizmalarmm Endovasküler Tedavisi}

\author{
Jian WANG ${ }^{1,2}$, Zhigang $\mathrm{SUN}^{1}$, Jinsuo $\mathrm{BAO}^{2}$, Zhaohui $\mathrm{LI}^{1}$, Dongsong $\mathrm{BAI}^{2}$, Shuwei $\mathrm{CAO}^{3}$ \\ ${ }^{1}$ China-Japan Union Hospital of Jilin University, Department of Neurosurgery, Changchun, Jilin, China \\ 2The Affiliated Hospital of Inner Mongolia National University, Department of Neurosurgery, Tongliao, Inner Mongolia, China \\ ${ }^{3}$ Weihai Municipal Hospital, Department of Interventional, Weihai, Shandong, China
}

Corresponding Author: Zhigang SUN / E-mail: ella--my707@163.com

\begin{abstract}
AIM: The prognosis of VBA aneurysms seems poor and surgical management of VBA dissecting aneurysms is challenging. We evaluated our endovascular experience in management of ruptured and unruptured VBA dissecting aneurysms.

MATERIAL and METHODS: Eleven consecutive patients with eleven VBA aneurysms (3 ruptured and 8 unruptured) between 2008 and 2010 were retrospectively reviewed.

RESULTS: Immediate postprocedural angiograms showed complete occlusion in 5 and subtotal occlusion in 2 aneurysms treated with stentassisted coiling, whereas no occlusion in 4 aneurysms treated with stenting alone. A clinical improvement or stable outcome was achieved in all patients. There was no complication in our patients and no patient died after treatment. Angiographic follow-up (mean 9.7 months, 1 to 23 months) showed complete cure in 8 aneurysms, subtotal occlusion in 2 and no occlusion in 1.
\end{abstract}

CONCLUSION: VBA dissecting aneurysms can be managed by endovascular stent placement with or without coiling. In cases that cannot be treated with neurostents, proximal occlusion could be an option.

KEYWORDS: Aneurysm, Vertebrobasilar artery, Embolization

öz

AMAÇ: VBA anevrizmalarının prognozu kötüdür ve VBA disekan anevrizmalarının cerrahi tedavisi zordur. Rüptüre olmuş veya olmamış VBA disekan anevrizmalarının tedavisinde endovasküler deneyimimizi değerlendirdik.

YÖNTEM ve GEREÇLER: 2008 ve 2010 yılları arasında görülen VBA anevrizması bulunan (3 rüptürlü ve 8 rüptürsüz) arka arkaya 11 hasta retrospektif olarak gözden geçirildi.

BULGULAR: Işlemden hemen sonraki anjiyogramlar stent yardımlı sarmal konması ile tedavi edilmiş olan 5 anevrizmada tam oklüzyon ve 2 anevrizmada subtotal oklüzyon ve sadece stent konarak tedavi edilmiş 4 anevrizmada oklüzyon bulunmadığını gösterdi. Tüm hastalarda klinik bir düzelme veya stabil sonuç elde edildi. Hastalarımızda bir komplikasyon olmadı ve hiçbir hasta tedaviden sonra ölmedi. Anjiyografik takip (ortalama 9,7 ay, 1-23 ay) 8 anevrizmada tam kür, 2 anevrizmada subtotal oklüzyon ve 1 anevrizmada oklüzyon bulunmamasını gösterdi.

SONUÇ: VBA disekan anevrizmaları sarmal konarak veya konmadan endovasküler stent yerleştirmeyle tedavi edilebilir. Nörostentlerle tedavi edilemeyen vakalarda proksimal oklüzyon bir seçenek olabilir.

ANAHTAR SÖZCÜKLER: Anevrizma, Vertebrobaziler arter, Embolizasyon

\section{INTRODUCTION}

VBA dissecting aneurysms are rare lesions associated with significant morbidity and death $(26,34,35)$. The clinical manifestations of VBA dissecting aneurysms include SAH, brainstem compression, or ischemia $(4,10,24,33)$. Regardless of presentation, the prognosis for VBA dissecting aneurysms seems to be worse than that for VA dissecting aneurysms. ${ }^{35}$ Management of these lesions is controversial and difficult, and requires particular care. The purpose of this study was to evaluate endovascular management of VBA dissecting aneurysms.

\section{CLINICAL MATERIAL and METHODS}

Between 2008 and 2010, we treated 11 patients with a VBA dissecting aneurysm with endovascular techniques. The 11 patients included 7 men and 4 women who ranged in age from 13 to 67 years (mean age 42.2 years). Seven (63.6\%) patients with more than 40 years in age had a mean 12-year (range 1- to 30-year) history of hypertension, and no patient had a history of head trauma. Three patients had ruptured VBA dissecting aneurysms and 8 had unruptured dissecting aneurysms. Patient who had atherosclerotic dissections without aneurismal dilation are not considered in this paper.

\section{Endovascular Management}

The procedure was performed under general anesthesia and therapeutic heparinization with activated clotting time of approximately 300 seconds. Giant dissecting aneurysms 
with enough collateral blood flow were treated with proximal occlusion. Aneurysms with partially thrombosis or mild dilation were treated with stenting alone. Dissections with aneurismal dilation were treated with stent-coiling. Stents placement with or without coiling were performed in 9 patients and proximal vertebral artery occlusion techniques in 2 patients as previously described (11). In all cases, a stent was positioned into the lumen of the parent vessel bridging the aneurysm with reconstruction of the vessel comparable to an "endovascular bypass." The stents available included Neuroform stents, Leo stents and Enterprise stents. Subsequently, the aneurysm was coiled with platinum coils in 5 cases. Immediate post procedure angiograms were obtained and reviewed in multiple views, including standard lateral and anteroposterior projections.

\section{Premedication for Stent Placement}

In unruptured VBA dissecting aneurysms, patients were preloaded with the dual antiplatelet agents, $75 \mathrm{mg}$ clopidogrel daily and $200 \mathrm{mg}$ aspirin daily for 3 days before treatment. In ruptured VBA aneurysms, patients were preloaded with 300 $\mathrm{mg}$ clopidogrel and $300 \mathrm{mg}$ aspirin 2 hours before procedure. Post procedure, the patients were kept on a dual antiplatelet regimen ( $75 \mathrm{mg}$ clopidogrel daily and $200 \mathrm{mg}$ aspirin daily) between 3 and 6 months.

\section{Clinical and Angiographic Outcome Measures}

Follow-up clinical evaluations were assessed according to the GOS (12). Immediate post procedure and followup angiography measured aneurysm occlusion using the Raymond classification scale, (27) which primarily was developed for berry-shaped aneurysms.

\section{RESULTS}

Clinical and radiographic results are summarized in Table I. Dissecting aneurysms were characterized by the angiographic appearance with a focal vessel wall irregularity, a peri-aneurismal narrowing and a fusiform dilation. On MRI, intramural thrombus, an irregular vessel wall and a vessel wall flap can be seen. The aneurismal size = ranged from 2.5 to 29 $\mathrm{mm}$ (mean $13.0 \mathrm{~mm}$ ).

\section{Ruptured VBA dissecting aneurysms}

Three (27.3\%) ruptured dissecting aneurysms (Table I) were found. According to Hunt-Hess grade, one was grade I and two were grade III. One of 3 aneurysms was treated with stent placement alone, and two were treated with stentassisted coiling (Figure $1 A, B ; 2 A, B$ ). In the aneurysm treated by stenting alone, contrast residual time within the aneurysm was increased moderately after the stent placement. Excellent clinical and technical results were achieved in these 3 patients without any periprocedural complications. A follow-up angiogram was available in these 3 patients at an average of 10.7 months (range, 3 to 20 months). Aneurismal neck recanalization was observed in 1 patient, who was treated with stent-assisted coiling during a 9-month follow-up. Follow-up angiography demonstrated complete occlusion at 3-month follow-up in the aneurysm treated with stenting alone. None of the patients presenting initially with $\mathrm{SAH}$ experienced aneurysm rupture during the observation period.

\section{Unruptured VBA Dissecting Aneurysms}

Eight $(72.7 \%)$ patients had unruptured VBA dissecting aneurysms (Table I). Among these patients, 4 (50\%) presented with massive effect, 2 (25\%) were diagnosed incidentally and $2(25 \%)$ presented with ischemia caused by a dissecting aneurysm. Three unruptured aneurysms were treated with stent-assisted coiling, 3 aneurysms were treated with stenting alone and 2 were treated with VA occlusion. Complete occlusion was observed in 3 aneurysms ( 1 treated with stentcoiling and 2 with VA occlusion). Filling of a residual base (Raymond Class 2) was observed in 2 aneurysms treated

Table I: Summary of Patients, Aneurysms and Treatments

\begin{tabular}{|c|c|c|c|c|c|c|c|c|}
\hline $\begin{array}{c}\text { Patient } \\
\text { No. }\end{array}$ & $\begin{array}{c}\text { Age/ } \\
\text { sex }\end{array}$ & $\begin{array}{c}\text { Presenting } \\
\text { symptoms }\end{array}$ & $\begin{array}{c}\text { Size } \\
(\mathrm{mm})\end{array}$ & Treatment & $\begin{array}{c}\text { Immediate } \\
\text { occlusion }\end{array}$ & $\begin{array}{c}\text { Follow-up } \\
\text { (months) }\end{array}$ & $\begin{array}{c}\text { Follow-up } \\
\text { angiography }\end{array}$ & Clinical \\
outcome
\end{tabular}


with stent-coiling. In the 3 patients treated by stenting alone, increased contrast residual time within the aneurysm was observed after the stent placement. A follow-up angiogram was available in all patients at an average of 9.4 months (range, 1 to 23 months). None of these patients experienced aneurysm rupture during the observation period. No aneurysm showed recanalization. Of the 3 aneurysms treated with stenting alone, follow-up angiography showed complete aneurysm occlusion during a more than 3-month observation period in 2 aneurysms and showed no change at 1-month follow-up in 1. There was no periprocedural complication. The 2 patients who had neurological deficits caused by ischemia experienced improvement at follow-up.

\section{DISCUSSION}

Symptoms of VBA aneurysms depend especially on the mech-
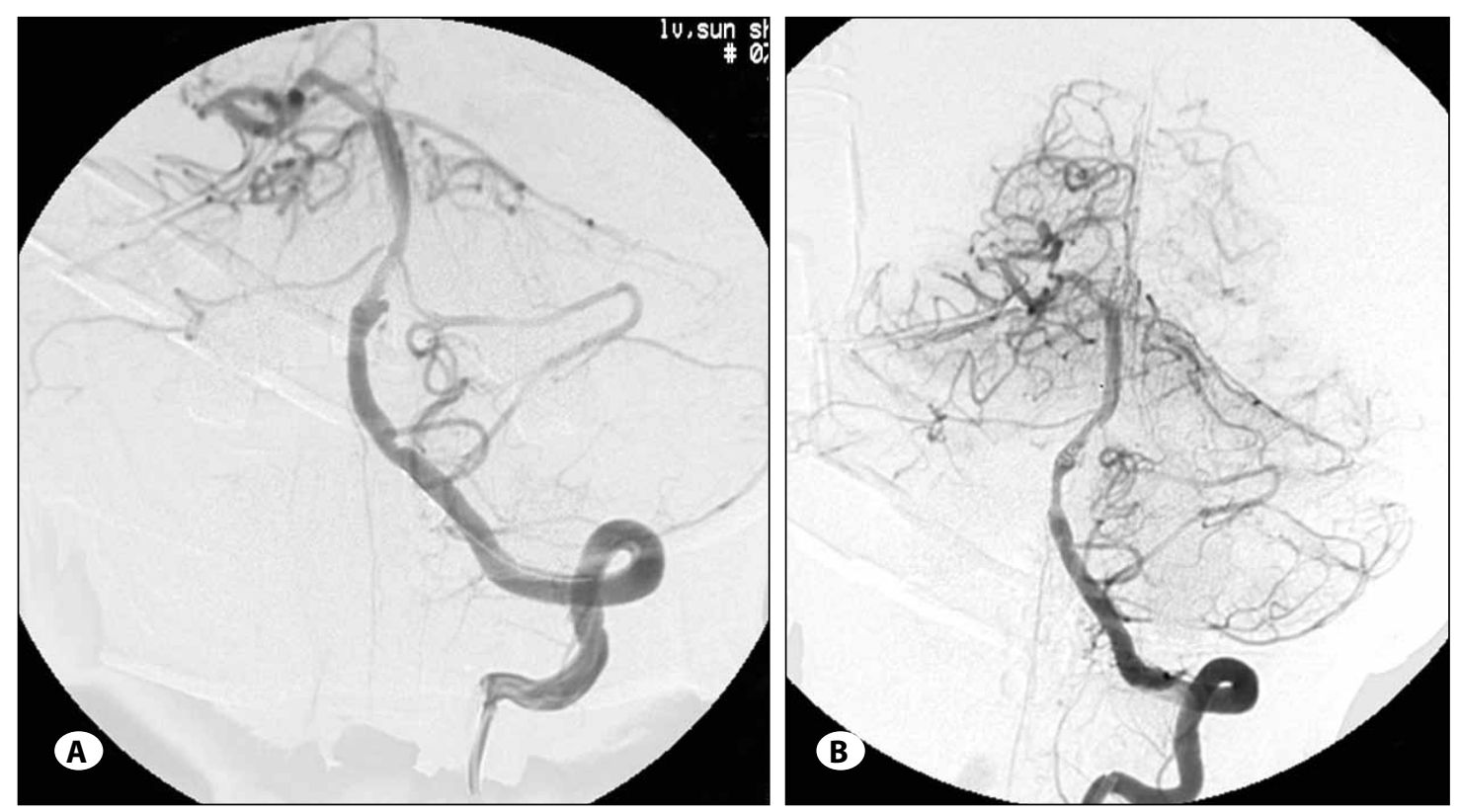

Figure 1: A) Left vertebral angiogram in a frontal view shows a dissecting aneurysm of the basilar trunk proximal to the AICA. B)Left vertebral angiogram in a frontal view after treatment shows the aneurysm is stented (Enterprise stent, $4.5 \times 28-\mathrm{mm}$ ) and coiled completely.
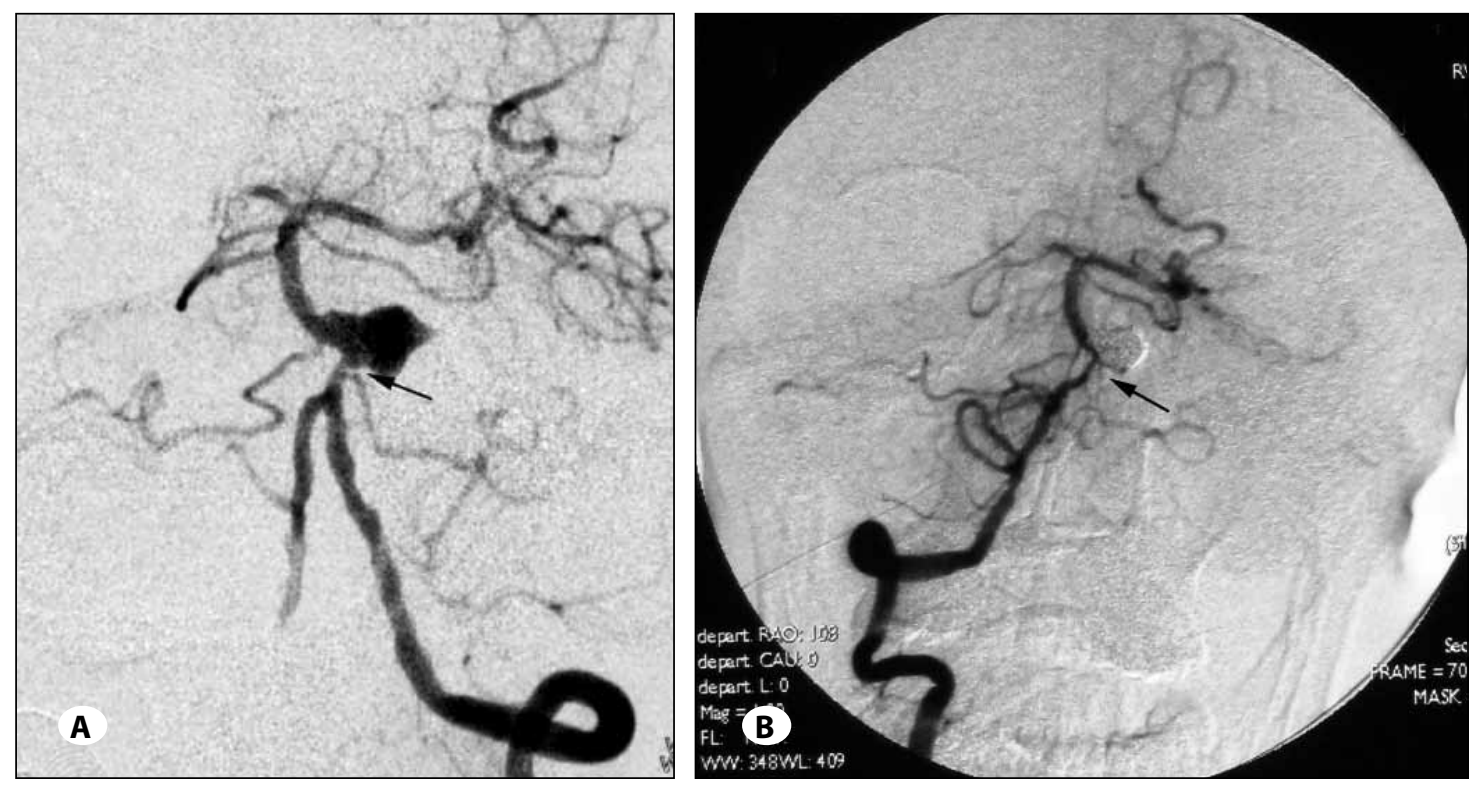

Figure 2: A) Left vertebral angiogram in a frontal view shows a dissecting aneurysm of the basilar trunk at the AICA with the area of dissection (arrow); note the AICA originating within the involved segment. B) Right vertebral angiogram in a frontal view after treatment shows the aneurysm is stented (Enterprise stent, $4.5 \times 28-\mathrm{mm}$ ) and coiled completely. The AICA was preserved(arrow). Follow-up angiography at 10 months (not shown) shows no coil compaction or aneurysm regrowth. 
anism: whether dissecting aneurysm or not, and ruptured or not. Typical presentations include mass effect, subarachnoid hemorrhage or ischemia. VBA dissecting aneurysms are rare and challenging diseases with a high associated morbidity and mortality. The pathogeneses of VBA dissecting aneurysms seems to be fibro-muscular dysplasia in patients less than 40 years in age and hypertension in patients more than 40 years in age $(15,16)$. There is a hypertension history in patients more than 40 years in age and no head trauma history in all patients.

Advances in angiography and MR imaging have increased the recognition that intracranial VBA dissecting aneurysms, unruptured VBA dissecting aneurysms accounts for $72.7 \%$ in our study. The natural history, treatment, and outcome of VBA dissecting aneurysms have rarely been analyzed. $(2,3,9,12,20,23,25,26)$. Only in a few cases mentioned in a series on VA dissection, $(5,6,13,21,34)$ approximately $30-70 \%$ of patients with ruptured vertebrobasilar dissecting aneurysms will have rebleeding, while smaller percentages will stabilize or improve without treatment $(7,10,13,21,33)$. A review of $B A$ dissection in patients presenting with $\mathrm{SAH}$ included eight patients and revealed a death rate of $50 \%$ and good recovery in only $25 \%$ of patients (9). Pozzati, et al., (26) reported on six patients with dissecting aneurysm of the BA, one of whom died of catastrophic recurrent hemorrhage. The other five patients were treated conservatively, with three eventually making a good recovery. In a review by Masson, et al., (20) 30 of 38 patients died because of their lesions. Brainstem ischemia was the mode of presentation in 27 patients, SAH in five, and both in six. Yoshimoto, et al. (35) reported on 10 patients with BA dissections, 1 of whom died of recurrent hemorrhage. Four patients presented with $\mathrm{SAH}, 5$ patients had brainstem ischemia and 1 presented with mass effect. Eight patients were treated conservatively but did not recover. Rabinov et al (11) reported that the mortality rate in the treated group was $20 \%$, whereas in the untreated group it was $50 \%$. There is likely a selection bias in these literature reviews as highergrade hemorrhages were seen more often in the untreated group, but VBA dissecting aneurysms thus carried significant morbidity and death whether they presented with ischemia or SAH. Early treatment seems essential for improving the prognosis in these patients.

Treatment strategies of VBA dissecting aneurysms should take the underlying pathomechanism into consideration and include, depending on the presentation, medical treatment, parent vessel occlusion, flow reversal or diversion, surgical options or a combined treatment protocol $(2,3,11,28,29,31)$. A typical VA dissecting aneurysm can be treated relatively safely with either surgical or endovascular proximal artery occlusion $(4,8,21)$. Nonetheless, the risk of producing neurological sequelae as a result of interrupting blood flow of the perforators arising from the VBA appears to be much greater. Ongoing advances in endovascular techniques ultimately may make stent placement with or without coil embolization one of the best management strategies for these lesions. The existing data regarding the use of cerebral stents are promising, but longer follow-up studies are needed to evaluate the dynamics and delayed effects of these stents on the cerebral vasculature. Remarkable flow reduction and decrease in shear stress have been demonstrated in aneurysm sac models by placing a stent alone across the neck of the aneurysm $(14,30)$. Furthermore, the measured flow velocity and shear stress consistently decrease with the addition of each successive stent. Thrombosis of the aneurysm sac has also been reported after a stent is placed across the aneurysm neck even without coil embolization, and this might offer a potential treatment option in selected cases $(1,22,32)$. A group of 28 dissecting aneurysms was treated with this method with no additional stroke or rehemorrhage (31). Our results demonstrate that treatment is indicated for most of these lesions. Our series confirms the efficacy and safety of stent-assisted coiling with the Enterprise device. Moreover, the Enterprise stent appears very easy to navigate and to position, on account of its delivery system and we believe that the Enterprise stent is currently the stent that is easiest to place. The densely woven mesh of current flow diversion stents may constitute a treatment alternative since this mesh may help in pushing the dissection flap back against the wall, thereby preventing further progression of the dissection. However, this new device is still not available in China.

Parent vessel occlusion still plays a role in VBA dissecting aneurysms, which cannot be stented for a giant partially thrombosed aneurysm. Redekop, et al., (28) described a patient with SAH caused by a dissecting aneurysm involving both VAs as well as the basilar trunk; a staged bilateral VA occlusion was performed successfully. After occlusion, the BA was filled in a retrograde fashion through the posterior communicating artery (Pcoma). In another report the authors have described BA (or bilateral VA) occlusion for treatment of complex aneurysms (29). The size of the Pcomas proved to be a good predictor of the ability to tolerate BA occlusion. Basilar artery or bilateral VA occlusion might be considered appropriate treatment in the event of recurrent or progressive enlargement of the BA aneurysm, provided that the patient's Pcomas would provide demonstrably ample collateral flow $(16,29)$. Balloon test occlusion may be of benefit to determine if the collateral circulation is limited anatomically or compromised by vasospasm (11).

Both the clinical course and the therapeutic approach for an unruptured BA dissecting aneurysm are complex $(1,5,22,32,35,36)$. When the lesion involves the BA, however, various upper brainstem deficits are likely, such as hemi- or tetraparesis, diplopia, disturbance of consciousness, and facial palsy (36). Severe neurological impairment in many patients deterred us from using anticoagulants for fear of bleeding. Although the exact mechanisms of progression in this subcategory remain unclear, several researchers have indicated that these dissecting aneurysms form a spectrum of vascular abnormalities ranging from small fusiform aneurysms to symptomatic giant, so-called dolichoectatic aneurysms $(23,24)$. When these lesions involve the BA, they may cause serious progressive brainstem compression (23). 
Radiological follow up in six patients with BA dissecting aneurysm was reported to reveal spontaneous healing of the dissecting aneurysm in two, improvement in two, stability in one, and worsening in one (26). In patients with VA dissecting aneurysms, the lateral medullary syndrome is a common clinical presentation of brainstem ischemia (36). However, lesions caused by dissecting aneurysm often resolved spontaneously after endovascular treatment $(17,18)$. Based on these experiences, we treat these lesions endovascularly to stop the dissecting process, though a therapeutic strategy for unruptured BA dissecting aneurysms has not yet been established.

In patients treated with stent-coiling, aneurysms may regrow over time, maybe due to coil compaction or the fact that the pathological process is maintained in the vessel wall $(19,37)$. Therefore, these patients should be followed closely. Followup for most cases should be performed at 6-12 months if the lesion is initially treated to complete obliteration. If the occlusion is stable, it is considered cured. If there is residual aneurismal filling at the time of initial therapy, 1- to 6-month follow-up could be considered.

\section{CONCLUSIONS}

VBA dissecting aneurysms are rare lesions associated with significant morbidity and death. Endovascular stent placement with or without coiling and parent vessel occlusion could be the options for VBA dissecting aneurysms. Unruptured VBA dissecting aneurysms should also be treated to stop its progression. Regardless of treatment choice, these patients need to be followed up closely.

\section{REFERENCES}

1. Ahna JY, Hanc IB, Kimc TG, Yoond PH, Leed YJ, Leee BH, Seob $\mathrm{SH}$, Kimb DI, Honga CK, Jooa JY: Endovascular treatment of intracranial vertebral artery dissections with stent placement or stent-assisted coiling. AJNR Am J Neuroradiol 27(7): 1514-1520, 2006

2. Ali MJ, Bendok BR, Tella MN, Chandler JP, Getch CC, Batjer $\mathrm{HH}$ : Arterial reconstruction by direct surgical clipping of a basilar artery dissecting aneurysm after failed vertebral artery occlusion: Technical case report and literature review. Neurosurgery 52: 1475-1481, 2003

3. Amin-Hanjani S, Ogilvy CS, Buonanno FS, Choi IS, Metz LN: Treatment of dissecting basilar artery aneurysm by flow reversal. Acta Neurochir 139:44-51, 1997

4. Anxionnat R, de Melo Neto JF, Bracard S, Lacour JC, Pinelli C, Civit T, Picard L: Treatment of hemorrhagic intracranial dissecting aneurysms. Neurosurgery 53:289-301, 2003

5. Berger MS, Wilson CB: Intracranial dissecting aneurysm of the posterior circulation. Report of six cases and review of the literature. J Neurosurg 61:882-894, 1984

6. de Bray JM, Penisson-Besnier I, Dubas F, Emile J. Extracranial and intracranial vertebrobasilar dissecting aneurysms: Diagnosis and prognosis. J Neurol Neurosurg Psychiatry 63:46-51, 1997
7. Friedman $A H$, Drake CG: Subarachnoid hemorrhage from intracranial dissecting aneurysm. J Neurosurg 60:325-334, 1984

8. Hamada J, Kai Y, Morioka M, Yano S, Todaka T, Ushio Y: Multimodal treatment of ruptured dissecting aneurysms of the vertebral artery during the acute stage. J Neurosurg 99:960-966, 2003

9. Hosoda K, Fujita S, Kawaguchi T, Shose Y, Yonezawa K, Shirakuni T, Hamasaki M: Spontaneous dissecting aneurysms of the basilar artery presenting with a subarachnoid hemorrhage. Report of two cases. J Neurosurg 75:628-633, 1991

10. Iwama T, Andoh T, Sakai N, Iwata T, Hirata T, Yamada H: Dissecting and fusiform aneurysms of vertebro-basilar systems. MR imaging. Neuroradiology. 32:272-279, 1990

11. Rabinov JD, Hellinger FR, Morris PP, Ogilvy CS, Putman CM: Endovascular management of vertebrobasilar dissecting aneurysms. AJNR Am J Neuroradiol 24:1421-1428, 2003

12. Jennett $B$, Bond $M$ : Assessment of outcome after severe brain damage. A practical scale. Lancet 1:480-484, 1975

13. Kaku Y, Yoshimura S, Yamakawa H, Sakai N: Failure of stentassisted endovascular treatment for ruptured dissecting aneurysms of the basilar artery. Neuroradiology 45(1):22-26, 2003

14. Kallmes DF, Ding YH, Dai D, Kadirvel R, Lewis DA, Cloft HJ: A new endoluminal, flow-disrupting device for treatment of saccular aneurysms. Stroke 38:2346-2352, 2007

15. Lv X, Jiang C, Li Y Yang X, Wu Z: Endovascular treatment for pediatric intracranial aneurysms. Neuroradiology 51:749-754, 2009

16. Lv X, Jiang C, Li Y, Yang X, Wu Z: Treatment of giant intracranial aneurysms. Interv Neuroradiol 15:135-144, 2009

17. Lv X, Jiang C, Li Y, Wu Z: Clinical outcomes of ruptured and unruptured vertebral artery-posterior inferior cerebellar artery complex dissecting aneurysms after endovascular embolization. AJNR Am J Neuroradiol 31:1232-1235, 2010

18. Lv X, Jiang C, Li Y, Wu Z: Clinical outcomes of lower cranial nerve palsies caused by vertebral artery-postero inferior cerebellar artery aneurysms after endovascular embolization. Neurol Res 32:796-800, 2010

19. Mackey $\mathrm{Cl}$, Han PP, Albuquerque FC, McDougall CG: Recurrence of a vertebral artery dissecting pseudoaneurysm after successful stent-supported coil embolization: Case report. Neurosurgery 53:754-761, 2003

20. Masson C, Krespy Y, Masson M, Colombani JM: Magnetic resonance imaging in basilar artery dissection. Stroke 24:1264-1266, 1993

21. Mizutani T, Aruga T, Kirino T, Miki Y, Saito I, Tsuchida T: Recurrent subarachnoid hemorrhage from untreated ruptured vertebrobasilar dissecting aneurysms. Neurosurgery 36: 905-913, 1995

22. Miyachi S, Negoro M, Okamoto T, Suzuki O, Yoshida J: Endovascular treatment of unruptured vertebro-basilar aneurysms. Interv Neuroradiol 5:83-88, 1999 
23. Mizutani T: A fatal, chronically growing basilar artery: A new type of dissecting aneurysm. J Neurosurg 84:962-971, 1996

24. Nakatomi H, Segawa H, Kurata A, Shiokawa $Y$, Nagata $K$, Kamiyama $\mathrm{H}$ : Clinicopathological study of intracranial fusiform and dolichoectatic aneurysms: Insight on the mechanism of growth. Stroke 31:896-900, 2000

25. Odabasi Z, Kutukcu Y, Gokcil Z, Vural O, Yardim M: Traumatic basilar artery dissection causing locked-in syndrome. Minim Invasive Neurosurg 41:46-48, 1998

26. Pozzati E, Andreoli A, Padovani R, Nuzzo G: Dissecting aneurysms of the basilar artery. Neurosurgery 36:254-258, 1995

27. Raymond J, Guilbert F, Weill A, Georganos SA, Juravsky L, Lambert A, Lamoureux J, Chagnon M, Roy D: Long-term angiographic recurrences after selective endovascular treatment of aneurysms with detachable coils. Stroke 34: $1398-1403,2003$

28. Redekop G, TerBrugge K, Willinsky R: Subarachnoid hemorrhage from vertebrobasilar dissecting aneurysm treated with staged bilateral vertebral artery occlusion: The importance of early follow-up angiography: Technical case report. Neurosurgery 45: 1258-1263, 1999

29. Steinberg GK, Drake CG, Peerless SJ: Deliberate basilar or vertebral artery occlusion in the treatment of intracranial aneurysms. Immediate results and long-term outcome in 201 patients. J Neurosurg 79:161-173, 1993
30. Treatment of experimental carotid aneurysms by endoprosthesis implantation: Preliminary report. Neurol Res 15:181-184, 1993

31. Stent-assisted reconstructive endovascular repair of cranial fusiform atherosclerotic and dissecting aneurysms: Longterm clinical and angiographic follow-up. 39:3288-3296, 2008

32. Yamasaki S, Hashimoto K, Kawano Y, Yoshimura M, Yamamoto T, Hara M:Treatment of vertebro-basilar dissecting aneurysms using intravascular stents. Interv Neuroradiol 12:137-144, 2006

33. Yamaura A, Watanabe Y, Saeki N: Dissecting aneurysms of the intracranial vertebral artery. J Neurosurg 72:183-188, 1990

34. Dissection of the V4 segment of the vertebral artery: Clinicoradiologic manifestations and endovascular treatment. Eur Radiol 17:983-993, 2007

35. Yoshimoto Y, Hoya K, Tanaka Y, Uchida T: Basilar artery dissection. J Neurosurg 102:476-481, 2005

36. Yoshimoto Y, Wakai S: Unruptured intracranial vertebral artery dissection. Clinical course and serial radiographic imagings. Stroke 28:370-374, 1997

37. Zhang J, Zhang R, Wu Z, Lv X, Liu B: Results of endovascular management for mid-basilar artery aneurysms. Interv Neuroradiol 16:249-254, 2010 